\title{
The "Place Experience" as a Key for Local Development: a Theoretical Framework
}

\author{
Giulio Maggiore $^{1, a}$, Piera Buonicontri ${ }^{2, b}$ \\ ${ }^{1}$ Università Telematica Unitelma Sapienza, Viale Regina Elena n. 295, 00161 Roma, Italy \\ ${ }^{2}$ Istituto di Ricerche sulle Attività Terziarie (CNR), Via G. Sanfelice n.8, 80134 Napoli, Italy \\ agiulio.maggiore@unitelma.it, ${ }^{b}$ p.buonincontri@irat.cnr.it
}

\begin{abstract}
Keywords: Tourism Experience, Customer Experience, Tourist Satisfaction, Sustainable Tourism, Territorial Marketing.
\end{abstract}

\begin{abstract}
The promotion of local economic development processes in a metropolitan area often depends on its ability to attract sustainable tourism flows and to provide a high quality of life for citizens. Both are basic conditions to enhance the competitiveness of an urban context, but their achievement is possible only if territorial planning strategies are focused on the real "experience" lived by tourists and citizens while they get in touch (either virtually or physically) with that place. This is the reason why all the choices made by policy makers, urban planners, and territorial marketing managers should be aimed at promoting the best experience possible for people visiting and living the city. Thus, there is a need for theoretical models able to support practitioners in their efforts for "experience design", which can find in the marketing literature - and in particular in the studies on tourism experience - many interesting conceptual references. This research topic has grown very rapidly in the last years, but at the moment is still characterized by a high fragmentation and a lack of systematic theoretical models. Starting from these considerations, the purpose of the paper is to fill this gap by presenting a conceptual framework specifically developed in order to give a solid basis for the design, management and evaluation of the experiences lived by people when they plan, visit and remember a place.
\end{abstract}

\section{Introduction}

Cities are first of all places where people spend a significant amount of their time doing something useful, interesting or enjoyable. This is true for residents living there, but also for tourists who visit the city for a short while and aim at exploiting every single moment spent there in order to justify the money and the time invested into that travel.

For this reason, city planners and policy makers should always consider the promotion of a positive experience for residents and visitors as one of the major guideline during the definition of development strategies for their metropolitan areas. It is very important to give relevance not only to the needs of tourists, but also to those of residents, as a good quality of life is at least as much essential as tourists' satisfaction for the attractiveness of a territory. Furthermore, the attention to local community favours also the development of a sustainable tourism: it prevents degenerative phenomena that lead to over-exploitation of tourism resources, which reduce the long-term competitiveness of a destination.

City planners and policy makers have also to take into account that the experience lived by tourists is undoubtedly different from that lived by residents: the tourists' satisfaction depends only on the ability of the destination to offer a pleasant stay consistent with the tourists personal preferences, while the perception of quality of life by residents relies on many other factors, more articulated and complex. This implies that it is necessary to pay attention also to several different features of the territory. Nevertheless, it is possible to identify a least common multiple in the experience of the two types of users that can provide a useful point of reference: the experience of a "place" may actually be similar for those tourists who aim at immersing themselves into the genuine local culture, avoiding the clichés of mass tourism, and for those residents who aim at discovering the local cultural assets of 
their land, going beyond the mere functional exploitation of the local resources. Both seek to build a personal relationship with the city, getting in touch with its real identity and carrying back a non-stereotypical memory, made of unique emotions, innovative ideas, and new knowledge.

This combination of cognitive inputs, emotions, feelings, and perceptions may be defined as "place experience" and represents the main source of tourist satisfaction and one of the primary building blocks of the quality of life for the local inhabitants. The place experience cannot be planned a priori, as it is by definition the fruit of a spontaneous and subjective process which takes shape within the individual consciousness, but it is possible to create the best conditions to favour its positive development.

Marketing scholars have discovered the importance of this issue many years ago, focusing on customer experience as the real outcome of every commercial transaction and as one of the main concerns of business managers [1,2,3]. More recently, this concept has become popular in the economy of tourism where there is a reach research stream focused on the study of the tourism experience $[4,5,6,7]$.

In spite of the growing interest about the topic, there is still a lack of systematic approaches to this field and a high fragmentation tends to prevail. Besides, also the works devoted to the tourism experience focus on the demand side, while there is little attention to the territory as a possible source of experience.

This paper aims at giving a contribution to fill both these gaps by presenting a theoretical framework where the "place experience" is considered as a specific and explicit goal of a rational design process carried out by policy makers and managers in which the needs of residents and tourists are both considered as crucial concerns.

\section{The customer experience: a theoretical background}

The experiential approach has made its first appearance in the studies on consumer behaviour with the work of Hirschman and Holbrook [8], who highlighted the need to find new conceptual categories to study what they call the "hedonic consumption", focusing on the emotional and multisensory aspects of consumer activity and rejecting the idea that the decision-making process is based only on rationality.

This experiential perspective, opposed to the traditional information processing view, has enjoyed increasing success, especially since the nineties, as it has intercepted some cultural trends typical of the post-modern era, which recognize the central importance of new concepts, such as complexity, subjectivity and sociality [9].

This success has led some authors to state that we are now entering the stage of the "experience economy" where firms are required to "orchestrate memorable experiences" for their customers rather than just to sell products able to satisfy their functional needs [1]. Symbolic elements become more important and consumption behaviours must be analyzed in their composite aspects which include cognitive, emotional and sensory dimensions [10,3]. Furthermore, due to the fact that experiences are characterized for being personal and unique for each customer, interaction among firms and customers has become essential and the role of firms is shifting from the mere delivery of products and services to the creation of an experience environment [17].

Recently, this perspective has been adopted even in the field of tourism, where the correspondence between product and experience is more manifest, as creating experiences is the essence and the raison d'etre of the tourism industry: tourists usually travel to live experiences, and the competitive advantage of a destination depends primarily on its ability to meet such an expectation [4] and to offer an experience environment where tourists may combine different local resources in order to live their unique and memorable experiences. Above and beyond the recurring references to the importance of the experiential view in the process of tourism consumption, the literature has also sought to identify the factors that contribute to the quality and memorability of the experience, in order to provide tourism managers with effective conceptual tools, allowing them to seize the opportunities offered by 
this new approach $[4,5,6,7]$. Interesting advancements in the state of the art of knowledge about tourism experience have been done, but still do not offer a sufficient conceptual basis for an effective management of the process of experience design, that represents the critical trial for tourism and territorial managers.

In order to answer to this need, it is necessary to go a step further by trying to combine the most significant findings emerged from the literature within a single theoretical framework that takes into account not only the antecedents of the experience, but also the real possibility to interfere with the experiential process to determine positive feedbacks, and the role of the destination as en experience environment where tourists, residents, firms and local resources meet and dialogue.

The "place experience" model described below is an attempt to take this further step, with reference to the specific situation of a territory which may be envisioned as a tourist destination but also as a place of discovery and exploration for the resident population.

\section{The "place experience" model}

The promotion of positive and memorable experiences on a specific place (urban or rural area) depends on the presence of some favourable conditions which are in part related to some objective characteristics of the territory, in part may be the result of conscious strategies pursued by the local stakeholders, and in part are characterized by unpredictability because are related to demand's requirements. Therefore, to address the decision-making process towards solutions consistent with the potential of the area and with the expectations of the users, we need a unique and shared representation of the underlying logics that lead to the development of the experience.

This representation may be provided through a conceptual model which combines all the key elements which contribute to the experience-making. The model is based on a conceptual framework used to analyze the experiences lived by the participants to socio-cultural events and by the consumers of cultural products $[11,12,13]$, extended with some further constructs which have already been the object of a first empirical test [14].

The model consists of three complementary elements:

- the experience process, which is the dynamic representation of the progressive development of the experience along the time;

- the experience drivers, which are the factors that, through a dynamic and interdependent interplay, contribute to give the experience a specific form, improving its intensity and memorability;

- The experience mix, composed by a system of levers that policy makers and managers can use to enact the experience drivers.

The experience process. Experience is by definition a longitudinal concept, which takes shape and evolves over time along a complex process. This process may be split into three stages:

- Wait. This stage has also been defined of "anticipated consumption" [15] as it includes thoughts, feelings and sensory images about what the consumer imagines and foretastes when he becomes aware of his needs, collects information, evaluates the alternatives, plans the travel, books the services. The contact with the place is generally mediated by technology (web, television, etc.) and communication channels, either formal or informal: opinions expressed by other people are searched and often kept in high consideration.

- Action. The consumption stage may be considered the core of the whole process, when the representation takes shape, the "moment of truth", where the experience is usually richer and more intense. At this stage the consumer gets in touch with the place and interacts with it, visiting attractions, meeting people, tasting food in an immersive experience where feelings and multisensory inputs are generally dominant. 
- Memory. The time of "remembered consumption and nostalgia" can be envisioned as an extension of the experience lived on the field and reflects the memory of what has been done or seen: once the visitor is back at home, he recalls the emotions, the feelings and the information assimilated during the travel and shares them with his social network. Sometimes the experience is so strong that it causes a change in the habits and the culture of the visitor, affecting his lifestyle.

The experience drivers. The literature on the customer experience has highlighted some of the main factors which can play a role of antecedents in the development of a positive and memorable experience. Some are generic and can be applied to different consumption contexts. Others are specific to a particular market. Here we present a systematization of the field with particular regard to the context of "place consumption", which is our focus. In this context, we found that the main experience drivers are:

- the multidimensional personal engagement, which implies the contemporary solicitation of a person at the different levels of his nature (cognitive, affective, sensorial, etc.), so that he can simultaneously sense, feel, think, act and relate, living a "total experience" [2];

- the satisfaction of complementary needs, which implies the possibility to meet all the conscious and unconscious needs of a person, giving him the opportunity to enjoy a complete and interdependent set of activities (learning, socializing, having fun, eating excellent food, etc.);

- the evocation of symbolic values, which implies the ability to convey to the visitor deeper meanings that go beyond the superficial layer of his immediate experience, through the association with individual and collective myths evoked from his memory or introduced from the outside at the time of consumption [16];

- The experience self-determination, which implies the possibility granted to the user of designing and shaping his own experience, playing a leading role in a co-creation process where he can freely select and place the pieces of that unique "mosaic" corresponding to his personal experiential path [17].

- The interaction with the local community, which implies a human and cultural exchange between the tourists and the people living in the place visited, so that the visitors can immerse themselves in the daily life of the destination, participating actively in the activities that take place there and feeling as a part of that world [18].

The experience mix. The drivers described above are opportunities to favour the development of positive experiences, but, in order to exploit them, policy makers and managers have to use all the available levers. They have also to coordinate their activities, as the experience lived by customers is unique, while the supply of services is generally managed by many and heterogeneous organizations.

Usually, the mix may be structured into three areas (product, environment, services) which all contribute to shape the customer experience [19], but in the case of "place experience", we propose the following classification:

- the resources, which include all the attractions located in a specific place (museums, monuments, natural reserves, etc.), that are part of the cultural heritage of the area, which usually polarize the interest of visitors;

- the context, formed of all the environmental factors which affect the process of consumption, including everything that is external to the people (physical factors, social factors, cultural factors);

- The services, including all the activities, managed by private or public organizations, which develop interactions with the visitors (communication, information, assistance, etc) in order to facilitate or enrich their experience.

Managing the levers of the experience mix in the three areas described which correspond to three different layers of action, policy makers and local managers can activate the five experience drivers 
along the whole experience process, accompanying the visitor during the discovery of the place he is exploring (Fig. 1).

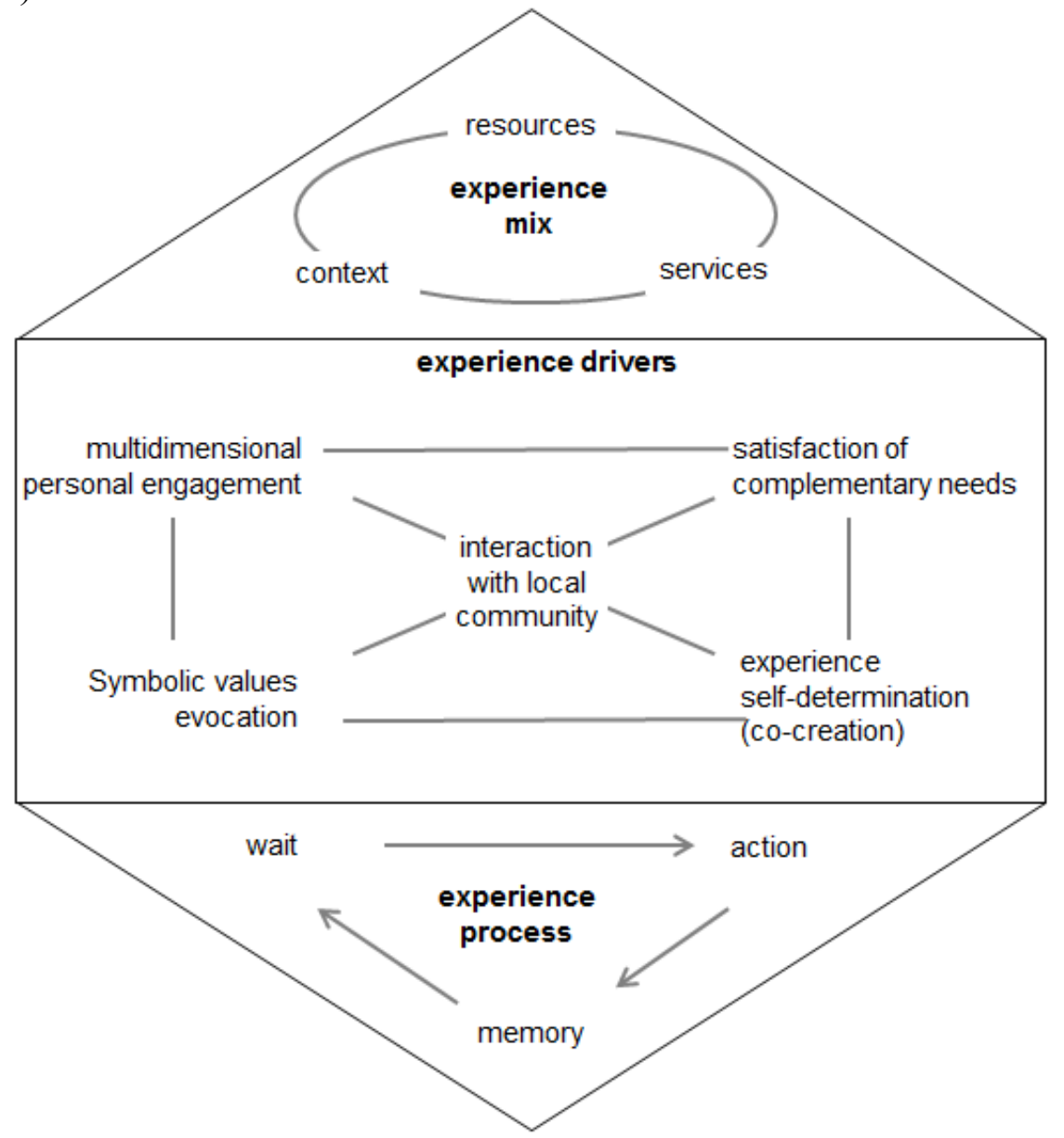

Fig. 1: The model of "place experience"

\section{Conclusions}

The model of "place experience" provides tourism and city managers with a conceptual tool which allows a systematic approach to the problem solving related to their activities. It can play a substantial role in improving their capabilities to address their decision-making process towards goals consistent with the achievement of valuable outcomes in terms of tourist satisfaction and quality of life for residents.

It can also give a contribution to the development of the debate on tourism experience as it presents an innovative systematization of a literature characterized by a high degree of fragmentation and can lay the groundwork for a more detailed study of the phenomenon. For a consolidation of the model and a detailed operationalization of the variables, it is required a further advancement of research with the development of an empirical analysis based on case studies and direct surveys. These activities will be developed in the coming months.

\section{Acknowledgements}

This work was financially supported by the National Research Council (CNR) and by the Italian Ministry of Education, Universities and Research (MIUR) as a part of the Project "NeoLuoghi", funded by the Program PON 'Ricerca e Competitività 2007-2013'. 


\section{References}

[1] B. J., Pine and J.H. Gilmore: The Experience Economy. Work is Theatre \& Every Business a Stage, Harvard Business School Press, Boston, Massachusetts (1999)

[2] B. H. Schmitt: Experiential Marketing, Free Press, New York (1999)

[3] R. Resciniti: Il marketing orientato all'esperienza. L'intrattenimento nella relazione con il consumatore, Edizioni Scientifiche Italiane, Napoli (2004)

[4] S. H. Tsaur, Y. T. Chiu and C.H. Wang: The visitors behavioral consequences of experiential marketing. In: Journal of Travel and Tourism Marketing, vol. 21, n. 1 (2007), pp. 47-64

[5] V. W. S. Tung and J. R. B. Ritchie: Exploring the essence of memorable tourism experiences. In: Annals of Tourism Research, Vol. 38, n. 4 (2011), pp. 1367-1386

[6] J. R. B. Ritchie, V.W.S. Tung and R.J.B. Ritchie: Tourism experience management research: Emergence, evolution and future directions. In: International Journal of Contemporary Hospitality Management, vol. 23, n. 4: (2011), pp. 419 - 438

[7] J. H. Kim, J. R. B. Ritchie and B. McCormick: Development of a scale to measure memorable tourism experiences. In: Journal of Travel Research, vol. 10, n. 10, (2011), pp. 1-14

[8] E. C. Hirschman and M.B. Holbrook: Hedonic consumption: emerging concepts, methods and propositions. In: Journal of Marketing, vol. 46, n. 2, (1982), pp. 92-101

[9] G. Fabris: Il nuovo consumatore: verso il post-moderno, Franco Angeli, Milano (2003)

[10] A. Carù and B. Cova. (2003). Esperienza di consumo e marketing esperienziale: radici diverse e convergenze possibili. In: Micro \& Macro Marketing, vol. 12, (2003), pp. 187-211

[11] R. Resciniti and G. Maggiore (Eds): (2009), Event experience. Progettare e gestire eventi da ricordare, Edizioni Scientifiche Italiane, Napoli (2008)

[12] G. Maggiore and R. Resciniti: La prospettiva dei partecipanti: il modello dell'event experience. in Il valore degli eventi, edited by E. Bonetti, S. Cherubini, G. Iasevoli, and R. Resciniti, Franco Angeli, (2009), pp. 133-158

[13] G. Maggiore and R. Resciniti: Experiential marketing for value creation in cultural heritage management. In: Advances in tourism studies, edited by A. Morvillo, The McGraw-Hill Companies, Milano (2012), pp. 261-280

[14] P. Buonincontri and G. Maggiore: Costruire esperienze memorabili. Il caso dei Sassi di Matera, in: XVIII Rapporto sul Turismo Italiano 2011-12, edited by E. Becheri and G. Maggiore, Franco Angeli, Milano (2013), pp. 317-330

[15] E. Arnould, L. Price and G. Zinkhan: Consumers, 2nd ed., McGraw-Hill/Irwin, New York. (2004)

[16] B. H. Schmitt. and A. Simonson: Marketing aesthetics: The strategic management of brands, identity, and image, New York, Free Press (1997)

[17] C. K. Prahalad and V. Ramaswamy: The Future of Competition: Co-Creating Unique Value with Customers, Harvard Business School Press, Boston (2004)

[18] D. MacCannell: The Tourist: a new theory of the leisure class, Schocken Books, New York (1989)

[19] D. LaSalle and T.A. Britton: Priceless: turning ordinary products, into extraordinary experiences, Harvard Business School Press, Boston (2003) 